\title{
BÊNH LAO VÀ ĐÁI THÁO ĐƯờNG
}

Nguyễn Hải Thủy, Trần Thị Hồng Vân,

Truoòng Đại học Y Duợc Huế

DOI: 10.47122/vjde.2020.39.1

\section{ABSTRACT \\ Tuberculosis and diabetes mellitus}

Diabetes mellitus (DM) increases the risk of tuberculosis (TB) by 2-3 times and the risk of adverse TB treatment outcomes. Diabetes causes immunosuppression, is increasingly being recognized as an independent risk factor for tuberculosis, and the two often coexist and impact each other. There are two stages of tuberculosis (TB): latent TB infection and active TB disease. So that DM patients especially patients newly diagnosed with DM, systematic TB screening should be performed. TB causes "stress-induced hyperglycaemia" and this can make the management of DM more difficult. Treatment for drug-susceptible and drug-resistant TB is similar in patients without DM. Diabetes may also lead to severe disease, reactivation of dormant tuberculosis foci, and poor treatment outcomes. Tuberculosis as a disease entity on the other hand and some commonly used antituberculous medications separately may cause impaired glucose tolerance. Metformin is the first-line drug of choice for treating persons with DM if medication is needed to control elevated glucose levels. Insulin may have to be considered if blood glucose levels are very high or in those whose blood glucose levels are not controlled with oral hypoglycaemic drugs. Diabetic patients withs cardiovascular disease should be offeredlow dose aspirin and a statin, and need to be counselled about appropriate lifestyle management (smoking cessation, good diet and physical activity). The awareness of clinicians and managers of TB and diabetes programs on the effect of the interaction between these two disease entities very important not only for screening and but also managing diabetic patients with TB.

\section{TÓM TẮT}

Đái tháo đường làm gia tăng nguy cơ mắc lao gấp 2-3 lần và nguy cơ xuất hiện những bất lợi khi điều trị. Đái tháo đường gây nên ức chế miễn dịch, ngày càng được thừa nhận là một yếu tố nguy cơ của bệnh lao, và hai bệnh lý này tồn tại và tác động lẫn nhau. Bệnh lao có hai giai đoạn: lao tiềm ẩn và bệnh lao (lao hoạt động). Vì vậy, bệnh nhân đái tháo đường, đặc biệt mới được chẩn đoán, nên được sàng lọc bệnh lao có hệ thống. Bệnh lao gây nên tình trạng "tăng đường máu do stress", điều này dẫn đến việc điều trị đái tháo đường khó khăn hơn. Điều trị lao nhạy cảm thuốc hay lao kháng thuốc ở bệnh nhân mắc hay không đái tháo đường không khác nhau. Đái tháo đường có thể làm nặng nề hơn bệnh lao, làm tái hoạt các ổ lao không hoạt động, và làm giảm hiệu quả điều trị. Mặt khác bệnh lao là một bệnh lý thực thể và một số thuốc kháng lao sử dụng đơn độc có thể gây nên rối loạn dung nạp glucose. Metformin là thuốc được lựa chọn đầu tiên điều trị đái tháo đường nếu cần sử dụng thuốc để kiểm soát glucose máu. Insulin được cân nhắc nếu glucose máu cao hoặc glucose máu không được kiểm soát với thuốc hạ glucose máu đường uống. Bệnh nhân đái tháo đường có biến chứng tim mạch nên được sử dụng aspirin liều thấp và một thuốc nhóm statin, và cần được tư vân một lối sống phù hợp (không hút thuốc lá, chế độ ăn hợp lý và hoạt động thể lực). Nhận thức của các bác sĩ lâm sàng và nhà quản lý bệnh lao và đái tháo đường về sự tác động giữa hai bệnh lý này là rất quan trọng không chỉ về phương diện sàng lọc mà còn trong điều trị bệnh nhân đái tháo đường mắc lao.

Chịu trách nhiệm chính: Nguyễn Hải Thủy

Ngày nhận bài: 7/2/2020

Ngày phản biện khoa học: 12/3/2020

Ngày duyệt bài: 29/3/2020

Email: nhthuy52@gmail.com

ĐT: 0903574457 


\section{1. ĐĂT VẤN ĐỀ}

Đái tháo đường (ĐTĐ) là một bệnh mạn tính ngày càng có khuynh hướng gia tăng và cũng là một vấn đề sức khoẻ của nhân loại sau bệnh tim mạch với tỷ lệ lưu hành bệnh ĐTĐ đang gia tăng trên toàn cầu được thúc đẩy tình trạng béo phì trong dân chúng. Trong khi đó bệnh Lao, một bệnh lý nhiểm khuẩn chiếm tỷ lệ thấp ở các nước có đời sống thu nhập cao nhưng gia tăng ở những nước có tỷ lệ cao về nhiễm HIV, suy dinh dưỡng và đặc biệt những vùng dân cư sinh sống đông đúc, hoặc cơ sở hạ tầng y tế còn thấp.

Mối liên hệ giữa bệnh ĐTĐ và bệnh Lao đã được ghi nhận từ nhiều thế kỷ qua nhiều nghiên cứu đã ghi nhận bệnh ĐTĐ làm giảm sức đề kháng của người bệnh vì thế người bệnh ĐTĐ có nguy cơ mắc bệnh lao gấp 2-3 lần so với người không. ĐTĐ và chính sự gia tăng tần suất hiện nay của ĐTĐ là yếu tố làm bệnh lao quay trở lại vì vậy làm gia tăng gánh nặng về bệnh lao trên toàn cầu. Theo WHO, tỷ lệ bệnh nhân ĐTĐ trong số người bệnh lao khoảng $15 \%[7]$.

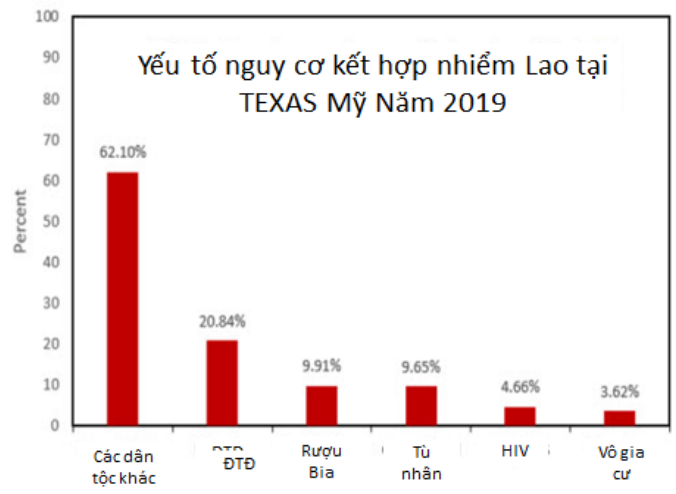

Bệnh Lao thường trải qua 2 giai đoạn lao tiềm ẩn (latent $\mathrm{TB}$ infection) và Lao tiến triễn (active TB disease). Vì vậy bệnh nhân ĐTĐ mắc lao thường được chẩn đoán muộn do các dấu hiệu và triệu chứng không điển hình, đồng thời ĐTĐ cũng làm giảm đi hiệu quả điều trị bởi khả năng đáp ứng điều trị chậm hơn so với bệnh nhân lao không mắc ĐTĐ, sự tương tác giữa thuốc kháng lao và thuốc hạ đường máu và tỷ lệ tác dụng không mong muốn của thuốc sử dụng xảy ra cao hơn ở nhóm bệnh nhân ĐTĐ mắc lao; làm tăng tỷ lệ tử vong và tái phát [8].

Trên thế giới, mỗi năm có khoảng 10 triệu người mắc lao mới. Tỷ lệ bệnh nhân ĐTĐ trong số người bệnh lao khoảng $15 \%$ theo WHO 2014 [7].

Số người mắc lao có đái tháo đường ở Việt Nam khoảng 0,4 triệu người vào năm 2018 [10].

Nghiên cứu tại Texas (Mỹ) năm 2019 ghi nhận yếu tố nguy cơ mắc bệnh Lao là ĐTĐ chiếm tỷ lệ $20,84 \%$.

\section{SINH LÝ BỆNH BỆNH LAO VÀ ĐÁI THÁO ĐƯờnG}

ĐTĐ gây ra tình trạng rối loạn chức năng miễn dịch, đặc biệt tăng đường máu gây ức chế miễn dịch qua trung gian tế bào [11]. Đại thực bào đóng vai trò trong bệnh sinh của bệnh lao, và cũng là tế bào khả năng diệt khuẩn mạnh nhất. ĐTĐ làm tổn thương các chức năng chính của đại thực bào như chức năng hoá ứng động, chức năng thực bào và chức năng diệt khuẩn. Mặt khác, hoạt động sản xuất oxít nitríc (NO) của đại thực bào là bước quyết định trong sự kiểm soát thành công nhiễm trùng lao và người ta thấy rằng hoạt động này bị giảm sút ở các bệnh nhân ĐTĐ mắc Lao.

Bên cạnh đó hoạt động của các bạch cầu đa nhân có vai trò quan trọng trong ngăn chặn nhiễm trùng lao thông qua sự phối hợp tạo thành $\mathrm{u}$ hạt cũng như góp phần vào hoạt động thực bào và sản xuất các cytokin; các hoạt động này cũng cho thấy bị suy giảm ở các bệnh nhân đái đường đặt biệt khi đường máu $\geq 220 \mathrm{mg} / \mathrm{dl}$. 


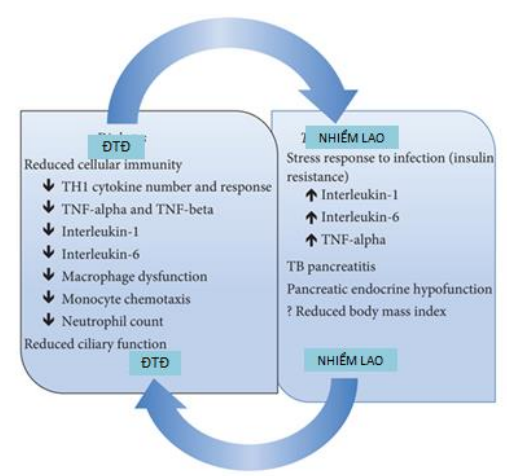

So đồ 1. Cơ chế bệnh sinh tương tác của bệnh lao và đái tháo đường ĐTĐ gây giảm miễn dich tế bào, Bệnh Lao làm tăng đường máu TH1: T-helper 1; TNF: tumor necrosis factor; TB: tuberculosis.

Ngoài ra, sự kiểm soát hiệu quả nhiễm trùng lao thông qua sự tạo thành $\mathrm{u}$ hạt phụ thuộc vào sự phát triển của đáp ứng miê̂̉n dịch mạnh loại TH1. Các cytokin TH1 có vai trò rất quan trọng trong kiểm soát và ức chế trực khuẩn lao. Chẳng hạn, interferon $-\gamma$ có vai trò quan trọng trong chống lại vi khuẩn và cả interferon $-\gamma$ cũng như yếu tố hoại tử $u$ $(\mathrm{TNF} \alpha)$ có tác động hoạt hoá đại thực bào. Đại thực bào được hoạt hoá phóng thích các chất trung gian oxy phản ứng và các gốc tự do như oxít nitríc có vai trò chủ yếu trong kiểm soát nhiễm trùng bao gồm cả vi khuẩn lao. Có bằng chứng cho thấy đái đường gây trở ngai các quá trình này. Sự giảm sút đáp ứng miễn dịch TH1 bao gồm Interleukin 12, Interferon $-\gamma$ và sự tổng hợp NO được ghi nhận ở các bệnh nhân đái đường. Có sự giảm đáp ứng miễn dịch TH1 qua kết quả định lượng hemoglobin glycat hoá. Sự rối loạn chức năng miễn dịch này gây bất lợi cho đáp ứng miễn dịch chống lại bệnh lao. Có thể nói rằng ức chế miễn dịch ở các bệnh nhân đái đường góp phần làm tăng nguy cơ mắc bệnh lao.

Nhiều nghiên cứu ghi nhận Stress là một nguyên nhân quan trọng gây ra rối loạn đường máu. Tăng đường máu trong bệnh Lao liên quan đến stress (stress-induced hyperglycaemia). Thật vậy tình trạng sốt, tình trạng ít hoạt động kéo dài và suy dinh dương trong bệnh lao cũng kích thích tiết các hormone chống điều hòa (Epinephrine, Glucagon, Cortisol và $\mathrm{GH}$ ) làm tăng đường máu. Rối loạn dung nạp đường không đơn giản chỉ là phản ứng với nhiễm trùng lao cấp mà còn là một tình trạng tiền đái đường ở bệnh nhân Lao.

Ngoài ra tác động của yếu tố viêm Interleukin 1,6 và $\mathrm{TNF} \alpha$ trong đáp ứng với nhiễm trùng lao có thể gây ra tăng sự đề kháng insulin. Bên cạnh đó, chức năng nội tiết của tụy cũng được thấy bị ảnh hương bất lợi ở trường hợp nhiễm lao nặng. Tỉ lệ cao của viêm tụy mạn canxi hoá xảy ra ở bệnh nhân lao phối hợp với ĐTĐ dẫn đến tình trạng thiếu hụt insulin tương đối hoặc tuyệt đối [13].

\section{PHÁC ĐỒ ĐIỀU TRI LAO \\ Các thuốc kháng Lao thiết yếu và nguyên tắc sử dụng}

Hiện có 5 thuốc kháng lao thiết yếu bao gồm Isoniazid, Rifampicin, Pyrazinamide, Ethambutol và Streptomycin.

- Isoniazid (H) là thuốc kháng lao có hiệu lực nhất và diệt được hầu hết các nhóm vi khuẩn trong những ngày đầu điều trị.

- Rifampicin (R) là một thuốc kháng lao thiết yếu khác.

Với hiệu quả của 2 thuốc trên, sau 2 tuần hầu hết bệnh nhân lao phổi trở thành nguồn lây ít nguy hiểm . Rifampicin cũng hoạt động chống lại trực khuẩn bán hoạt động và do đó thuốc là một tác nhân chống nhiễm trùng tốt và có hiệu quả trong việc ngăn ngừa tái phát bệnh. 
- Pyrazinamide (Z) là một thuốc diệt khuẩn quan trọng đối với nhóm vi khuẩn ở môi trường acid bên trong tế bào và đại thực bào. Pyrazinamide rất hiệu quả trong 2 tháng đầu nhưng lợi ích của thuốc sẽ ít hơn khi sử dụng kéo dài và vì vậy thuốc không được sử dụng trong giai đoạn duy trì.

- Ethambutol (E) là thuốc có tác dụng kiềm khuẩn, được sử dụng chính để ngăn ngừa sự xuất hiện kháng thuốc thứ phát của 3 thuốc kháng lao .

Streptomycin (S). Thuốc kháng sinh thuốc nhóm Aminoglycoside hiện cũng tái sử dụng trở lại.

Nguyên tắc điều trị lao luôn cần giai đoạn tấn công để tiêu diệt vi khuẩn đang hoạt động và bán hoạt động, theo sau đó là giai đoạn duy trì để diệt số lượng vi khuẩn còn lại.

Liệu pháp bốn thuốc kháng lao thiết yếu hàng 1 (RHZE) được sử dụng trong giai đoạn tấn công. Giai đoạn duy trì, số lượng vi khuẩn ít hơn và ít xuất hiện đột biến kháng thuốc chọn lọc hơn, vì vậy một số quốc gia chỉ sử dụng Rifampicin và Isoniazid, ở Việt Nam theo hướng dẫn của Bộ Y tế giai đoạn duy trì là 4 tháng với 3 thuốc Rifampicin, Isoniazid và Ethambutol.

\section{QUẢN LÝ BÊNH NHÂN LAO CÒN NHAY CẢM THUỐC \\ 4.1. Phác đồ điều trị: \\ Bệnh nhân lao mới lần đầu: Phác đồ6 \\ 4.2. Liều dùng thuốc kháng lao (Bảng 1)}

thángbao gồm Rifampicin (2RHZE/4RH hoặc 2RHZE/4RHE) được sử dụng trong trường hợp lao còn nhạy cảm thuốc. Giai đoạn tấn công 2 tháng gồm 4 thuốc RHZE. Giai đoạn duy trì 4 tháng gồm 2 thuốc RH hoặc 3 thuốc RHE, tốt hơn nên được giám sát trực tiếp.

Bệnh nhân đã từng điều trị lao: Đa phần bệnh nhân vẫn còn nhạy cảm thuốc, nên dùng phác đồ 6 tháng có Rifampicin vẫn được chỉ định nếu không có bằng chứng kháng thuốc.

Bệnh nhân mắc các thể lao ngoài phổi:

Lao màng não: Khuyến cáo thời gian điều trị 9-12 tháng do thể lao này có tỷ lệ tử vong và di chứng cao.

Lao xương khớp: Phác đồ điều trị 9 tháng do khó đánh giá đáp ứng điều trị.

Phối hợp glucocorticosteroid được khuyến cáo cho lao màng não và lao màng ngoài tim, theo dõi sát glucose máu rất cần thiết vì tác dụng tăng đường huyết của steroids. Theo hướng dẫn của Bộ Y tế Việt Nam, phác đồ điều trị lao đối với lao màng não, lao xương khớp và lao hạch là: $2 \mathrm{RHZE}(\mathrm{S}) / 10 \mathrm{RHE}$. Streptomycin được thay thế cho Ethambutol trong 2 tháng tấn công đối với lao màng não.

Lao đồng nhiễm HIV: Phác đồ điều trị lao là tương tự, mặc dù một số khuyến cáo là 9-12 tháng điều trị.

Theo dõi glucose máu thường xuyên sẽ cần thiết nếu có sử dụng glucocorticosteroid kèm theo để ngăn ngừa hoặc điều trị hội chứng phục hồi miễn dịch ở những bệnh nhân ĐТÐ.

Bảng 1. Liều khuyến cáo thuốc kháng lao ở người lớn mắc đái tháo đường

\begin{tabular}{|l|c|c|c|}
\hline \multirow{2}{*}{\multicolumn{1}{|c|}{ Thuốc }} & \multirow{2}{*}{ Ký hiệu } & \multicolumn{2}{c|}{ Liều khuyến cáo/ngày } \\
\cline { 3 - 4 } & & Liều (mg/kg) & Liều tối đa $(\mathbf{m g})$ \\
\hline Isoniazid & $\mathrm{H}$ & $5(4-6)$ & 300 \\
\hline Rifampicin & $\mathrm{R}$ & $10(8-12)$ & 600 \\
\hline Pyrazinamide & $\mathrm{Z}$ & $25(20-30)$ & - \\
\hline Ethambutol & $\mathrm{E}$ & $15(15-20)$ & - \\
\hline
\end{tabular}

Mặc dù liều 3 lần/tuần là được sử dụng ở một số quốc gia trong giai đoạn duy trì, điều này có thể tăng nguy cơ kháng Rifampicin ở bệnh nhân có hoặc không có đái tháo đường 
kèm theo. Do đó khuyến cáo rằng liều thuốc trong cả giai đoạn tấn công và duy trì là sử dụng hàng ngày.

Liều thuốc kháng lao có thể được cho theo nhóm cân nặng và viên thuốc kết hợp:

Để dễ dàng sử dụng, cung cấp và quản lý bệnh nhân, liều thuốc thường sử dụng theo 3 nhóm cân nặng $30-39 \mathrm{~kg}, 40-55 \mathrm{~kg}$ và $>55 \mathrm{~kg}$.

Sử dụng viên thuốc kết hợp (FDCs) cũng được khuyến cáo hơn vì hạn chế sự xuất hiện kháng thuốc, ít sai sót khi kê đơn và tuân thủ điều trị tốt hơn (Bảng 2).

Bảng 2. Cách điều trị với viên thuốc kết hợp được cho theo nhóm cân nặng ở người lớn.

\begin{tabular}{|c|c|c|c|c|}
\hline \multirow{2}{*}{$\begin{array}{c}\text { Thời gian sử } \\
\text { dụng }\end{array}$} & Thuốc kháng lao & \multicolumn{2}{|c|}{ Số viên thuốc kết hợp dùng hàng ngày } \\
\cline { 3 - 5 } & $\mathbf{3 0 - 3 9 k g}$ & $\mathbf{4 0 - 5 5 k g}$ & >55kg \\
\hline $\begin{array}{c}\text { 1-2 tháng giai } \\
\text { đoạn tấn công }\end{array}$ & $\begin{array}{c}\text { RHZE (R150mg, H75mg, } \\
\text { Z400mg, E275mg) } \\
\text { viên kết hợp }\end{array}$ & 2 & 3 & 4 \\
\hline $\begin{array}{l}\text { 3-6 tháng giai } \\
\text { đoạn duy trì }\end{array}$ & $\begin{array}{c}\text { RH (R150mg, H75mg) } \\
\text { viên kêt hợp }\end{array}$ & 2 & 3 & 4 \\
\hline
\end{tabular}

Chú ý:

Những bệnh nhân mới được xem là nhạy cảm với thuốc kháng lao, ngoại trừ:

Sống ở vùng có tỷ lệ kháng Isoniazid cao ở bệnh nhân lao mới, dựa vào những điều tra về tỷ lệ hiện mắc lao kháng thuốc. Trong một số trường hợp, bệnh nhân có thể điều trị RHE trong giai đoạn duy trì giống như một phương pháp thay thế cho RH được chấp nhận.

Bệnh nhân mắc lao sau khi tiếp xúc với bệnh nhân lao kháng thuốc. Kiểm tra tính nhạy cảm thuốc (KSĐ) nên được thực hiện trước điều trị và nên bắt đầu điề̀ trị khi có kết quả KSĐ.

\subsection{Theo dõi điều trị}

Bảng 3. Tác dụng không mong muốn của thuốc kháng lao hàng 1, mối liên quan với bệnh đái tháo đường và những xử trí được đề nghị

\begin{tabular}{|l|c|c|c|}
\hline \multicolumn{1}{|c|}{ Thuốc } & Tác dụng phụ & Sự xem xét khi có ĐTĐ & Xử trí \\
\hline Isoniazid & $\begin{array}{c}\text { Viêm TK ngoại } \\
\text { biên,Viêm gan }\end{array}$ & $\begin{array}{c}\text { Có thể nặng hơn khi có } \\
\text { ĐTĐ }\end{array}$ & $\begin{array}{c}\text { Pyridoxine (B6) } \\
\text { Ngừng tất cả thuốc }\end{array}$ \\
\hline Rifampicin & $\begin{array}{c}\text { RLdạ dày ruột } \\
\text { Viêm gan } \\
\text { Nước tiểu màu Đỏ }\end{array}$ & $\begin{array}{c}\text { Có thể xấu hơn khi có } \\
\text { metformin }\end{array}$ & $\begin{array}{c}\text { Điều trị triệu chứng } \\
\text { Ngừng tất cả thuốc } \\
\text { Giải thích }\end{array}$ \\
\hline Pyrazinamide & $\begin{array}{c}\text { Đau khớp } \\
\text { Viêm gan }\end{array}$ & $\begin{array}{c}\text { Gặp phổ biến hơn khi có } \\
\text { kèm ĐTĐ }\end{array}$ & $\begin{array}{c}\text { Aspirin hoặc NSAID } \\
\text { Ngưng tất cả thuốc }\end{array}$ \\
\hline Ethambutol & Viêm dây TK Thị & $\begin{array}{c}\text { Có thể xấu hơn khi có Bệnh } \\
\text { võng mạc ĐTĐ }\end{array}$ & Ngưng tất cả thuốc \\
\hline
\end{tabular}

Sự theo dõi đúng và có hệ thống dựa trên những ghi nhận tỉ mỉ là cần thiết để tạo ra kết quả điều trị và chủ yếu dựa vào hướng dẫn của chương trình chống lao.

- Theo dõi và ghi nhận tác dụng không mong muốn của thuốc kháng lao cần được phát hiện và xử trí sớm. Hầu hết bệnh nhân lao hoàn thành điều trị mà không xảy ra tác dụng phụ nào.

Tuy nhiên, một số ít bệnh nhân xuất hiện tác dụng phụ và cần được theo dõi lâm sàng. Theo dõi cận lâm sàng là không cần thiết. Nhân viên y tế phải giáo dục bệnh nhân phát hiện triệu chứng hoặc các dấu hiệu và báo cáo 
lại nếu chúng tiếp tục tăng lên.

Những tác dụng phụ chính của thuốc kháng lao hàng 1 (Bảng 3 ).

- Bệnh nhân lao phổi (soi đàm $(+)$, cấy đàm(+) hoặc được chẩn đoán theo các test nhanh của WHO, như Xpert MTB/RIF), soi đàm phát hiện nhóm vi khuẩn kháng acid cồn vào tháng thứ 2 , và lặp lại vào tháng thứ 5 và 6 của điều trị

- Cân nặng bệnh nhân nên được theo dõi hàng tháng.

4.4. Hướng dẫn Bộ $Y$ tế về điều trị người bệnh lao mắc đái tháo đường (Ban hành kèm theo Quyết định số: $3126 / \mathrm{Q} Đ-$ BYT ngày 23 tháng 5 năm 2018 của Bộ trưởng Bộ Y tế) - Điều trị cũng giống như đối với tất cả các bệnh nhân khác, bệnh nhân ĐTĐ có nguy cơ tổn thương thần kinh ngoại vi, thuốc INH có nguy cơ cao viêm thần kinh ngoại vi, do đó nên dùng thêm pyridoxin (10$25 \mathrm{mg} /$ ngày).

- Kết hợp chặt chẽ với thầy thuốc chuyên khoa để kiểm soát đường huyết, các biến chứng của ĐTĐ. Đảm bảo tối ưu kiểm soát đường huyết, khi đường huyết ổn định theo dõi lượng đường trong máu hàng tháng, giáo dục bệnh nhân tuân thủ điều trị, chế độ ăn uống, hoạt động thể chất.

- Xem xét đến tương tác thuốc trong việc kết hợp điều trị lao và điều trị ĐTĐ (rifampicin với nhóm sulphonylurea), cân nhắc sử dụng thuốc hạ đường máu bằng insulin, nhóm thuốc ít gây tương tác với thuốc lao: biguanide (Ví dụ: Metformin, không có tương tác với rifampicin, tuy nhiên, metformin gây tác dụng phụ đến hệ tiêu hóa khi kết hợp với thuốc lao và thận trọng những trường hợp suy gan, thận).

\section{TƯƠNG TÁC THUỐC KHÁNG LAO VÀ THUỐC HẠ ĐƯờNG MÁU}

Việc điều trị bệnh nhân ĐTĐ khi mắc lao đồng thời đòi hỏi phải đánh giá cẩn thận và lựa chọn thuốc hạ đường huyết và thuốc kháng Lao.

Nguyên tắc tiếp cận chung để kiểm soát bệnh ĐTĐ không khác nhau về sự hiện diện của bệnh lao hay không, mặc dù có thể có các tương tác thuốc - thuốc được mô tả dưới đây. Giống như điều trị bằng thuốc lao ảnh hưởng đến điều trị bệnh ĐTĐ, ngược lại bệnh ĐTĐ bản thân cũng có thể làm thay đồi dược động học của thuốc chống bệnh lao. Trong một nghiên cứu ở Indonesia, bệnh nhân đái tháo đường mắc bệnh lao có nồng độ huyết thanh Rifampicin thấp hơn $53 \%$ so với bệnh nhân lao không mắc bệnh ĐTĐ và có mối liên quan gián tiếp giữa nồng độ glucose máu đói và Rifampicin.

Bệnh đái tháo đường cũng có thể gây ra những thay đổi trong việc hấp thu thuốc qua đường uống, giảm liên kết protein của thuốc và suy thận hoặc gan nhiễm mỡ làm giảm thanh thải thuốc.

Tác dụng của nó đối với nồng độ thuốc kháng lao chưa được nghiên cứu chính thức; trong trường hợp đáp ứng kém với điều trị ở bệnh nhân đái tháo đường mắc bệnh lao, việc theo dõi thuốc điều trị có thể được xem xét [23].

Việc nồng độ thấp của thuốc chống lao có liên quan đển thất bại điều trị hoặc kháng thuốc, phát hiện trên đây là mối quan tâm hêt sức quan trọng. Mặc dù bệnh ĐTĐ có thể làm nặng bệnh lao, tăng tỉ lệ tử vong và tái phát, phác đồ điều trị và thời gian dùng thuốc chống lao ở những người bệnh lao có mắc hoặc không mắc ĐTĐ đều không khác nhau. 
Bảng 4. Phân loại các nhóm thuốc điều trị lao kháng thuốc (TCYTTG 2016)

\begin{tabular}{|c|c|c|c|}
\hline $\begin{array}{l}\text { A. Fluoroquinolones } \\
\text { (FQs) }\end{array}$ & & $\begin{array}{l}\text { Levofloxacin } \\
\text { Moxifloxacin } \\
\text { Gatifloxacin }\end{array}$ & $\begin{array}{l}\text { Lfx } \\
\text { Mfx } \\
\text { Gfx }\end{array}$ \\
\hline B.Thuốc tiêm hàng hai & & $\begin{array}{c}\text { Amikacin } \\
\text { Capreomycin } \\
\text { Kanamycin } \\
\text { Streptomycin }(*) \\
\end{array}$ & $\begin{array}{c}\mathrm{Am} \\
\mathrm{Cm} \\
\mathrm{Km} \\
\mathrm{S}\end{array}$ \\
\hline $\begin{array}{l}\text { C. Các thuốc hàng hai } \\
\text { chủ đạo khác }\end{array}$ & & $\begin{array}{l}\text { ionamide / Prothionamide } \\
\text { Cycloserine / Terizidone } \\
\text { Linezolid } \\
\text { Clofazimine }\end{array}$ & $\begin{array}{l}\text { Eto / Pto } \\
\text { Cs / Trd } \\
\text { Lzd } \\
\text { Cfz }\end{array}$ \\
\hline $\begin{array}{l}\text { D. Các thuốc bổ sung } \\
\text { (không thuộc nhóm } \\
\text { chủ đạo) }\end{array}$ & D1 & $\begin{array}{l}\text { Pyrazinamide } \\
\text { Ethambutol } \\
\text { H liều cao }\end{array}$ & $\begin{array}{c}\mathrm{Z} \\
\mathrm{E} \\
\mathrm{Hh}\end{array}$ \\
\hline & D2 & $\begin{array}{l}\text { Bedaquiline } \\
\text { Delamanid }\end{array}$ & $\begin{array}{l}\text { Bdq } \\
\text { Dlm }\end{array}$ \\
\hline & D3 & $\begin{array}{l}\text { p-aminosalicylic acid } \\
\text { Imipenem-cilastatin } \\
\text { Meropenem } \\
\text { Amoxicillin-clavulanate } \\
\text { Thioacetazone }\end{array}$ & $\begin{array}{c}\text { PAS } \\
\text { Ipm } \\
\text { Mpm } \\
\text { Amx-Clv } \\
\text { T }\end{array}$ \\
\hline
\end{tabular}

\subsection{Thuốc kháng lao}

Hầu hết các các quốc gia khuyến cáo điều trị bệnh lao trong 6 tháng, bao gồm:

Giai đoạn tấn công ban đầu là 2 tháng RHZE (Rifampicin, Isoniazid, Pyrazinamide và Ethambutol) và Giai đoạn duy trì kéo dài 4 tháng với RHE (Rifampicin, Isoniazid và Ethambutol) hoặc với RH (Rifampicin và Isoniazid) [14], [15], [16].

Tuy nhiên trên thực tế lâm sàng điều trị lao trên bệnh nhân ĐTĐ khá phức tạp do sự tương tác về dược động học và dược lực học giữa thuốc kháng lao và thuốc chống hạ đường huyết.

\section{Rifampicin}

Rifampicin, là thuốc kháng lao chính yếu trong các loại thuốc chống lao, thông qua cảm ứng enzyme, Thuốc làm gia tăng quá trình chuyển hóa thuốc Sulphonylureas và Biguanide, do đó làm giảm nồng độ các thuốc hạ đường huyết này trong huyết tương và dẫn đến tăng đường huyết sau đó. Những người không mắc bệnh ĐTĐ thuốc cũng làm gia tăng sự hấp thụ glucose của đường tiêu hóa [17]. Trên bệnh nhân ĐTĐ týp 2, Rifampicin là một chất cảm ứng mạnh mẽ của một loạt các enzyme chuyển hóa, bao gồm enzyme hệ thống cytochrom P450 và enzyme pha II. Việc tạo ra các enzyme này có thể dẫn đến tăng tốc độ chuyển hóa của các loại thuốc dùng chung với Rifampicin và làm giảm hiệu quả điều trị. Các sulphonylureas là một trong những thuốc hạ đường huyết uống được sử dụng phổ biến nhất cho bệnh nhân mắc đái tháo đường không phụ thuộc Insulin. Glyburide và Glipizide đều là chất nền của cytochrom P450 isoenzyme P2C9 (CYP2C9), và các nghiên cứu dược động học cho thấy nồng độ trong huyết thanh của các thuốc này giảm lần lượt $39 \%$ và $22 \%$ khi dùng chung với Rifampicin. Dữ liệu dược lực học cho thấy thêm rằng tác dụng hạ đường huyết của Glyburide giảm khi dùng đồng thời với Rifampicin [18].

Trên bệnh nhân ĐTĐ týp 1, nhu cầu insulin có thể tăng khi dùng Rifampicin. Rifampicin đã được chứng minh là gây tăng đường huyết giai đoạn đầu với giảm Insulin máu liên quan ngay cả ở những bệnh nhân không mắc bệnh tiểu đường. Tác dụng trực tiếp và gián tiếp của Rifampicin đối với việc kiểm soát đường huyết đòi hỏi phải theo dõi cẩn thận để điều chỉnh liều thích hợp ở bệnh nhân ĐTĐ mắc bệnh lao [19]. 
Tuy nhiên Nijland HM và các cộng sự ở Indonesia ghi nhận ở 17 bệnh nhân mắc lao và đái tháo đường, khi sử dụng được $450 \mathrm{mg}$ Rifampicin $(10 \mathrm{mg} / \mathrm{kg})$ và $600 \mathrm{mg}$ isoniazid 3 lần mỗi tuần so với 17 bệnh nhân chỉ mắc lao không ĐTĐ ghi nhận nồng độ Rifampicin thấp hơn $53 \%$ ở bệnh nhân mắc lao và đái tháo đường so với bệnh nhân chỉ mắc lao. Nghiên cứu này chỉ ra bệnh nhân mắc lao và đái tháo đường có trọng lượng cơ thể cao hơn có thể cần một liều Rifampicin nhiều hơn. Với nồng độ Rifampicin (AUC (0-6 giờ)) là $12,3 \mathrm{mg}$ xh /L ở bệnh nhân mắc lao và đái tháo đường, và $25,9 \mathrm{mg} \mathrm{xh} / \mathrm{L}$ ở bệnh nhân chỉ mắc lao $(\mathrm{P}=0,003)$.

\section{Isoniazid}

Isoniazid là thuốc kháng lao có tính đối kháng với tác dụng của sulphonylureas và làm kiểm soát đường huyết kém. Trong một số tình huống, Isoniazid làm giảm chuyển hóa các thuốc chống hạ đường huyết bằng đường uống và làm gia tăng nồng độ trong huyêt tương của chúng, như cytochrom P2C9 (CYP2C9) liên quan đến chuyển hóa sulphonylureas; tuy nhiên, người ta cho rằng tác dụng gây ra của Rifampicin vượt xa hiệu ứng ức chế này của isoniazid. Rifampicin và Isoniazid không rỏ cơ chế tác động đến sự phân hủy của insulin do insulin bị suy giảm chủ yếu do quá trình thủy phân các cầu nối liên kết disulphide thông qua hoạt động của enzyme phân hủy insulin ở gan [20].

\subsection{Thuốc hạ đường máu ở bệnh nhân ĐTĐ týp 2 mắc bệnh Lao}

Bệnh nhiễm trùng làm cho sự kiểm soát đường máu kém và bệnh lao cũng không ngoại lệ. Mặc dù bệnh Lao phổi cũng có thể gây ra rối loạn dung nạp glucose và có thể khởi đầu cho bệnh nhân bị đái tháo đường tiềm ẫn, các loại thuốc kháng lao được sử dụng để điều trị bệnh lao cũng có thể làm sự kiểm soát đường huyết xấu đi ở bệnh nhân mắc bệnhtiểu đường.

Ngoài ra độc tính và tác dụng không mong muốn của các thuốc cũng cần phải xem xét khi đồng điều trị bệnh lao vàbệnh ĐTĐ, chẳng hạn như bệnh thần kinh ngoại biên do điều trị bằng isoniazid vì thế dự phòng nguy cơệnh lý thần kinh ngoại biên, pyridoxine (B6) nên được dùng với isoniazid trong điều trị bệnh lao ở bệnh nhân ĐTĐ.

Ngoài ra, Rifampicin có thể gây tăng đường huyết trực tiếphoặc gián tiếp thông qua tương tác với thuốc hạ đường huyết đường uống.Rifampicin là một chất cảm ứng mạnh mẽ của một loạt các enzyme chuyển hóa, bao gồm cả hệ thống enzyme cytochromP450 và enzyme pha II. Việc tạo ra các enzyme này có thể dẫn đến tăng tốc độ chuyển hóa của thuốc dùng chung với rifampicin và làm giảm hiệu quả điều trị.

\section{Metformin}

Metformin là thuốc sử dụng đầu tiên cho bệnh nhân ĐTĐ týp 2, nhóm thuốc này không kích thích tiết insulin, chủ yếu giảm tân sinh đường ở gan và kháng insulin vì thế Metformin dùng đơn độc không gây hạ đường huyết. Metformin không được chuyển hóa bởi enzyme $\mathrm{P} 450$, và do đó không bị giảm nồng độ do tác dụng cảm ứng của Rifampicin trên enzyme chuyển hóa. Tuy nhiên, việc sử dụng metformin có thể bị ảnh hưởng vì metformin là chất nền cho các chất vận chuyển cation hữu cơ của con người và các chất vận chuyển khác. Rifampicin làm tăng biểu hiện của chất vận chuyển cation hữu cơ (OCT1) và tăng sự hấp thu Metformin của gan dẫn đến tác dụng hạ đường huyết tăng cường ở người khỏe mạnh. Có thể kể những bất lợi của việc sử dụng metformin ở bệnh nhân lao bao gồm nguy cơ tác dụng phụ như rối loạn đường tiêu hóa và rất hiếm khi nặng như nhiễm toan lactic.

\section{Sulfonyl Urea (SU)}

SU là một trong những thuốc hạ đường huyết uống thường dùng nhất cho bệnh nhân mắc ĐTĐ týp 2 sau thất bại Metformin Glyburide và Glipizide đều là chất nền của cytochrom P450 isoenzyme 2C9(CYP2C9). Khảo sát dược lực học ghi nhận tác dụng hạ đường huyết của Glyburide bị giảm khi dùng Rifampicin.Niemi $M$ và $C S$ đã thực hiện hai nghiên cứu chéo, ngẫu nhiên, 2 pha với thiết kế giống hệt nhau nhằm nghiên cứu tác dụng của Rifampin (INN, rifampicin) trên dược động học và dược lực học của Glyburide (INN, glibenclamide) và Glipizide đã được tiến hành. 
Trong mỗi nghiên cứu, 10 tình nguyện viên khỏe mạnh đã nhận được 600 mg Rifampin hoặc giả dược mỗi ngày một lần trong 5 ngày. Vào ngày thứ 6 , một liều duy nhất $1,75 \mathrm{mg}$ Glyburide (nghiên cứu I) hoặc $2,5 \mathrm{mg}$ Glipizide (nghiên cứu II) bằng đường uống. Đo nồng độ Glyburide và Glipizide huyết tương và đường huyết trong 12 giờ. Rifampin làm giảm nồng độ của Glyburide xuống 39\% và giảm tác dụng của Glyburide trong huyết tương (thời gian bán hủy của Glyburide được rút ngắn từ 2,0 xuống còn 1,7 giờ $(\mathrm{P}<0,05))$ nhưng chỉ có tác dụng nhẹ với Glipizide (giảm $22 \%$ nồng độ của Glipizide $(\mathrm{P}<0,05))$.

Insulin là lựa chọn sau cùng cho bệnh nhân ĐTĐ týp 2 trong số 3 thuốc nói trên trừ những trường hợp bệnh nhân đã sử dụng insulin từ trước khi chẩn đoán lao. Insulin được chỉ định trong những trường hợp tăng đường máu nặng (ví dụ, $\mathrm{HbA1c}>10 \%$ hoặc FBG $>15 \mathrm{mmol} / 1(270 \mathrm{mg} / \mathrm{dl}))$ hoặc không kiểm soát đường máu sau khi sử dụng metformin và các thuốc uống khác.

Bệnh nhân ĐTĐ týp 1 mắc bệnh lao ghi nhận nhu cầu insulin có thể tăng khi dùng Rifampicin.

Rifampicin đã được chứng minh là gây ra tăng đường huyết giai đoạn đầu kèm cường insulin (hyperinsulinism) ngay cả ở bệnh nhân không đái tháo đường.

\section{Các thuốc điều trị đái tháo đường ảnh hưởng đến điều trị lao}

Bảng 5. Thuốc hạ đường máu sử dụng phổ biến trong điều trị ĐTĐ Týp 2 ở bệnh nhân mắc lao

\begin{tabular}{|c|c|c|c|}
\hline Đặc điểm & Metformin & Dẫn xuất của $\mathrm{SU}$ & Insulin \\
\hline Thuốc lựa chọn & $\begin{array}{l}\text { Lựa chọn đầu } \\
\text { tay }\end{array}$ & $\begin{array}{l}\text { - Thêm vào } \\
\text { - Sử dụng trong trường hợp } \\
\text { CCĐ hoặc không dung nạp } \\
\text { Metformin }\end{array}$ & $\begin{array}{l}\text { Nếu mục tiêu HbA1c } \\
\text { hoặc FBG không đạt } \\
\text { hoặc tăng đường máu có } \\
\text { triệu chứng }\end{array}$ \\
\hline $\begin{array}{l}\text { Nguy co hạ } \\
\text { đường máu }\end{array}$ & Không & Có & Có \\
\hline Liều khởi trị & $\begin{array}{l}\text { 500mg/ngày, } \\
\text { tăng dần tối đa } \\
2000 \mathrm{mg} / \mathrm{ngày}\end{array}$ & $\begin{array}{l}\text { Gliclazide } 40-80 \mathrm{mg} \\
\text { Glibenclamide } 2.5-5 \mathrm{mg} \\
\text { Glimepiride } 1-2 \mathrm{mg} \\
\text { Glipizide } 5 \mathrm{mg}\end{array}$ & $\begin{array}{l}\text { Khởi đầu bằng } 10 \text { UI } \\
\text { nền mỗi ngày }\end{array}$ \\
\hline $\begin{array}{l}\text { Tương tác với } \\
\text { Rifampicin }\end{array}$ & $\begin{array}{l}\text { Không liên quan } \\
\text { đến lâm sàng }\end{array}$ & $\begin{array}{l}\text { Giảm } 30-80 \% \text { hiệu quả khi } \\
\text { dùng kèm Rifampicin }\end{array}$ & Không \\
\hline $\begin{array}{l}\text { Tác dụng phụ } \\
\text { chính }\end{array}$ & $\begin{array}{l}\text { RL dạ dày ruột } \\
\text { Nhiềm toan acid } \\
\text { lactic }\end{array}$ & Hạ đường máu & Hạ đường máu \\
\hline $\begin{array}{l}\text { Bệnh nhân có } \\
\text { giảm chức năng } \\
\text { thận }\end{array}$ & $\begin{array}{l}\text { Hiệu chỉnh theo } \\
\text { MLCT } \\
\text { eGFR }< \\
\text { ml/min } \\
\text { CCĐ eGFR }<30 \\
\text { ml/min }{ }^{\mathrm{a}}\end{array}$ & $\begin{array}{l}\text { Tăng nguy cơ hạ đường } \\
\text { máu } \\
\text { Nhóm Gliclazide }\end{array}$ & An toàn khi sử dụng \\
\hline Biến chứng TM & Có lợi & Trung tính & Trung tính \\
\hline
\end{tabular}

a: nếu không xác định được eGFR thì metformin không nên chỉ định ở bệnh nhân có bệnh thận mạn tính nếu không có sự chấp thuận của bác sĩ điều trị.

Ước tính mức lọc cầu thận: eGFR (estimated glomerular filtration rate)

Thiazolidinediones (TZD) thường được sử dụng làm cơ chất cho các enzyme cytochrom P450. Rosiglitazone được chuyển hóa phần lớn bởi CYP2C8 và Rifampicin làm 
giảm nồng độ Rosiglitazone khoảng 54 -65\% và Pioglitazone khoảng $54 \%$.

Glinides: Nargetlinide (Starlix), nhóm thuốc gây tiết insulin tác dụng ngắn được sử dụng nhằm ngăn ngừa tăng đường huyết sau ăn, được chuyển hóa bằng cách biến đổi sinh học oxy hóa, với sự tham gia của CYP2C9 và CYP3A4;

Diện tích vùng dướiđường cong chỉ giảm $24 \%$ mà không có tác dụng đường huyết đáng kể khi dùng Rifampicin. Repaglinide, một loại thuốc liên quan nhóm Glinide khác, có một diện tích dưới đường cong bị giảm31\%$57 \%$ khi dùng với Rifampicin, mặc dù giảm tác dụng hạ glucose của nó một nghiên cứu và không thay đổi ở một nghiên cứu khác.

Tác dụng trực tiếp và gián tiếp của Rifampicin đối với việc kiểm soát đường huyết giúp theo dõi cẩn thận với điều chỉnh liều thích hợp của các thuốc tiểu đường cần thiết ở bệnh nhân ĐTĐ mắc bệnh lao.

Thuốc ĐTĐ thế hệ mới: Như Thuốc đồng vận thụ thể GLP-1 (Glucagon-like peptide 1 receptor agonists), ức chế enzym DPP-4 (dipeptidyl peptidase 4 inhibitors) và nhóm ức chế kênh đồng vận chuyển Natri- Glucose $($ SGLT2 $=$ sodium glucose transporter 2$)$ inhibitors chưa đề cập nhiều.

\section{KẾT LUẬN}

Mối liên hệ giữa đái tháo đường và bệnh lao đã được ghi nhận từ nhiều thế kỷ trong đó bệnh đái tháo đường là một yếu tố nguy cơ quan trọng đối với bệnh lao và có thể ảnh hưởng đến việc biểu hiện triệu chứng bệnh cũng như đáp ứng điều trị bệnh. Hơn nữa, bệnh lao còn có thể làm xấu đi tình trạng kiểm soát đường huyết ở những người ĐTĐ mắc bệnh Lao. Bệnh ĐTĐ có nguy cơ tăng gấp ba lần mắc bệnh lao hoạt động, do đó gánh nặng của bệnh tiểu đường loại 2 sẽ tăng lên giúp duy trì dịch bệnh lao hiện nay. Các khuyến nghị đã được đưa ra để sàng lọc hai chiều, nhưng bằng chứng khan hiếm về việc thực hiện các xét nghiệm bệnh lao cụ thể ở những người mắc bệnh tiểu đường, xét nghiệm bệnh tiểu đường cụ thể ở bệnh nhân lao, và sàng lọc và điều trị dự phòng nhiễm trùng lao tiềm ẩn ở những người mắc bệnh tiểu đường.

Bệnh nhân lao mắc bệnh tiểu đường có nồng độ thuốc trị lao thấp hơn và nguy cơ ngộ độc thuốc cao hơn so với bệnh nhân lao không mắc bệnh tiểu đường. Kiểm soát đường huyết tốt, làm giảm các biến chứng tiểu đường lâu dài và cũng có thể cải thiện kết quả điều trị bệnh lao, bị cản trở bởi viêm mãn tính, tương tác thuốc, tuân thủ điều trị dưới mức tối ưu và các yếu tố khác.

Bên cạnh các phương pháp điều trị bằng thuốc cho bệnh lao và tiểu đường, các can thiệp khác, như giáo dục,tăng cường theo dõi và can thiệp lối sống, có thể cần thiết, đặc biệt đối với bệnh nhân mắc bệnh tiểu đường mới được chẩn đoán hoặc những người bệnh cần insulin, quản lý lâm sàng bệnh nhân mắc cả hai bệnh ĐTĐ và Lao còn gặp nhiều khó khăn. Từ quan điểm hệ thống y tế, chuyển giao cách chăm sóc tối ưu và tích hợp các dịch vụ cho cả bệnh lao và ĐTĐ vẫn là một thách thức lớn ở nhiều quốc gia cần nhiều nghiên cứu bao gồm các đánh giá kinh tế về sàng lọc và hệ thống được khuyến nghị để quản lý bệnh lao đồng thời và bệnh đái tháo đường.

\section{TÀI LIÊU THAM KHẢO}

1. Bộ Y tế (2017), Giao ban Hoạt động Chương trình Chống lao năm 2017 và phương hướng hoạt động năm 2018, Hà Nội.

2. Bộ Y tế (2018), Hướng dẫn chẩn đoán, điều trị và dự phòng bệnh lao, NXB Y học Hà Nội.

3. Bộ Y tế (2018), Hướng dẫn chẩn đoán, điều trị và quản lý ĐTĐ tại Trạm Y tế, Hà Nội.

4. Bộ Y tế (2019), Thông cáo báo chí ngày thế giới phòng, chống lao 24/ 3 năm 2019, Hà Nội.

5. Phan Thanh Dũng (2012), Đặc điểm lao phổi ở bệnh nhân đái tháo đường, $\mathrm{Kỷ}$ yếu hội nghị khoa học, Kiên Giang.

6. ANNE LEEGAARD, ANDERS RIIS, JETTE B. KORNUM et all (2011) Diabetes, Glycemic Control, and Risk of Tuberculosis, Diabetes Care. 
7. Blanca I. Restrepo (2016), Diabetes and tuberculosis, Microbiol Spectr. Author manuscript;

8. Dooley KE, Tang T, Golub JE, Dorman SE, Cronin W (2009), Impact of diabetes mellitus on treatment outcomes of patients with active tuberculosis. Am J Trop Med Hyg; 80:634-39.

9. Ernest Yorke, Yacoba Atiase,Josephine Akpalu et all (2017), The Bidirectional Relationship between Tuberculosis and Diabetes, Hindawi Tuberculosis Research and Treatment.

10. International Union Against Tuberculosis and Lung Disease (2018), Management of Diabetes and Mellitus-Tuberculosis, A Guide to the essential practice.

11. Jean Jacques Noubiap, Jobert Richie Nansseu, Ulrich Flore Nyaga et all (2019), Global prevalence of diabetes in active tuberculosis: a systematic review and meta-analysis of data from $2 \cdot 3$ million patients with tuberculosis, Lancet
Infect Dis. Author manuscript

12. Kelly E Dooley and Richard E Chaisson et all (2009), Tuberculosis and diabetes mellitus: convergence of two epidemics, Lancet Infect Dis. Author manuscript.

13. Meghan A Baker et all (2011), The impact of diabetes on tuberculosis treatment outcomes: A systematic review, Baker et al. BMC Medicine

14. Niemi M, Backman JT, Neuvonen M, Neuvonen PJ, Kivisto KT (2001), Effects of rifampin on the pharmacokinetics and pharmacodynamics of glyburide and glipizide. Clin Pharmacol Ther. 2001; 69:400-06.

15. Nijland HM, Ruslami R, Stalenhoef JE, et al (2006), Exposure to rifampicin is strongly reduced in patients with tuberculosis and type 2 diabetes. Clin Infect Dis. 2006;43:848-54.

16. WHO (2016), Tuberculosis and diabetes. 